\section{JTI}

JOURNAL OF

TRAUMA AND INJURY

Received: December 17, 2019

Revised: February 20, 2020

Accepted: March 16, 2020

\section{Correspondence to}

Kyu-Hyouck Kyoung, M.D., Ph.D. Department of Surgery, Ulsan University Hospital, University of Ulsan College of

Medicine, 877 Bangeojinsunhwando-ro, Dong-gu, Ulsan 44033, Korea

Tel: $+82-52-250-7118$

Fax: +82-52-250-8150

E-mail: soprano62@hanmail.net

\title{
Feasibility of Early Definitive Internal Fixation of Pelvic Bone Fractures in Therapeutic Open Abdomen
}

\author{
Kyunghak Choi, M.D. ${ }^{1}$, Kwang-Hwan Jung, M.D., Ph.D. ${ }^{2}$, Min Ae Keum, M.D. ${ }^{1}$, \\ Sungjeep Kim, M.D., Ph.D. ${ }^{1}$, Jihoon T Kim, M.D., Ph.D. ${ }^{1}$, Kyu-Hyouck Kyoung, \\ M.D., Ph.D. ${ }^{1}$ \\ ${ }^{1}$ Department of Surgery, Ulsan University Hospital, University of Ulsan College of \\ Medicine, Ulsan, Korea \\ ${ }^{2}$ Department of Orthopedic Surgery, Ulsan University Hospital, University of Ulsan \\ College of Medicine, Ulsan, Korea
}

Purpose: Damage control laparotomy has contributed to improved survival rates for severe abdominal injuries. A large part of severe abdominal injury occurs with a concomitant pelvic bone fracture. The safety and effectiveness of internal fixation of pelvic bone fracture(s) has not been established. The aim of the present study was to evaluate infection risk in the pelvic surgical site in patients who underwent emergent abdominal surgery.

Methods: This single-center retrospective observational study was based on data collected from a prospectively maintained registry between January 2015 and June 2019. Patients who underwent laparotomy and pelvic internal fixation were included. Individuals $<18$ and $\geq 80$ years of age, those with no microbiological investigations, and those who underwent one-stage abdominal surgery were excluded. Comprehensive statistical comparative analysis was not performed due to the small number of enrolled patients.

Results: A total of six patients met the inclusion criteria, and the most common injury mechanism was anterior-posterior compression (67\%). The average duration of open abdomen was 98 hours (range, 44-198), and the time interval between abdominal closure and pelvic surgery was 98 hours. One patient (16.7\%) died due to multi-organ dysfunction syndrome. Micro-organisms were identified in the abdominal surgical site in five patients (83\%), with no micro-organisms in pelvic surgical sites. There was no unplanned implant removal.

Conclusions: Internal fixation of pelvic bone fracture(s) could be performed in the state of open abdomen, and the advantages of early fixation may countervail the risks for cross contamination.

Keywords: Abdominal injuries; Laparotomy; Pelvic bones; Fracture fixation; Infections 


\section{INTRODUCTION}

Damage control laparotomy (DCL) and effective resuscitation using the open abdomen technique have positively contributed to increased survival rates in patients experiencing multiple traumas [1-3]. In particular, open abdomen with a sequential or staged closure strategy alleviates abdominal pressure after exploration, and helps to avoid abdominal compartment syndrome and consequent multiple organ failure [4]. Nevertheless, a suitable intervalbetween definitive abdominal closure and fixation of associated fractures-remains controversial in the open abdomen technique.

In general, temporary external fixation, followed by definitive internal fixation after an appropriate resuscitation approach, is suitable for individuals who have sustained multiple traumas $[5,6]$. Recently, early definitive fixation has been reported to contribute to improved outcomes, especially in fractures of the spine and the extremities $[7,8]$. Nonetheless, many orthopedic and trauma surgeons hesitate to perform internal fixation with open abdominal surgery, particularly in cases of pelvic fracture(s). Commonly, the perception of delayed fixation arises from the risk for surgical site infection (SSI) from cross contamination originating from the intra-abdominal cavity. The aim of the present study was to evaluate infection risk in the pelvic surgical site in patients who underwent emergent abdominal surgery.

\section{METHODS}

This single-center, retrospective, observational study was based on data collected from a prospectively maintained registry. The study protocol was approved by the Institutional Review Board, which waived requirements for informed consent because no additional intervention was performed. Patients who underwent laparotomy and pelvic internal fixation surgery between January 2015 and June 2019 were evaluated. Patients $<18$ and $\geq 80$ years of age, those without microbiological investigation, and individuals who underwent one-stage abdominal surgery

Table 1. Baseline characteristics of enrolled patients

\begin{tabular}{|c|c|c|c|c|c|c|c|c|}
\hline Pt & Age & Sex & $\begin{array}{c}\text { Injury } \\
\text { mechanism }\end{array}$ & $\begin{array}{l}\text { Abdominal organ } \\
\text { injury }\end{array}$ & Pelvic ring injury & Associated injury & ISS & $\begin{array}{c}\text { Contaminated } \\
\text { AS }\end{array}$ \\
\hline 1 & 54 & Male & AP compression & $\begin{array}{l}\text { SMV transection } \\
\text { Liver laceration } \\
\text { Pancreatic injury }\end{array}$ & $\begin{array}{l}\text { Diastasis of } \\
\text { symphysis pubis }\end{array}$ & $\begin{array}{l}\text { Multiple rib fracture } \\
\text { Pneumothorax }\end{array}$ & 34 & No \\
\hline 2 & 22 & Female & Vertical shearing & Liver laceration & $\begin{array}{l}\text { Sacral fracture } \\
\text { Bilateral sup. \& } \\
\text { inf. ramus fracture }\end{array}$ & $\begin{array}{l}\text { Multiple rib fracture } \\
\text { Pneumothorax }\end{array}$ & 29 & No \\
\hline 3 & 52 & Male & AP compression & $\begin{array}{c}\text { Bladder rupture } \\
\text { Retroperitoneal } \\
\text { hemorrhage }\end{array}$ & Open book fracture & $\begin{array}{l}\text { Epidural hematoma } \\
\text { Skull fracture }\end{array}$ & 27 & No \\
\hline 4 & 72 & Female & $\begin{array}{l}\text { Lateral } \\
\text { compression }\end{array}$ & EIV laceration & $\begin{array}{l}\text { lliac fracture } \\
\text { Bilateral sup. \& inf. } \\
\text { ramus fracture }\end{array}$ & Ankle fracture & 29 & No \\
\hline 5 & 61 & Male & AP compression & $\begin{array}{l}\text { CIV and IIA transection } \\
\text { Rectal transection } \\
\text { Bladder rupture }\end{array}$ & $\begin{array}{l}\text { Pelvic ring } \\
\text { comminuted } \\
\text { fracture }\end{array}$ & $\begin{array}{l}\text { Subdural hematoma } \\
\text { Perineal and inguinal } \\
\text { laceration }\end{array}$ & 59 & Yes \\
\hline 6 & 62 & Male & AP compression & $\begin{array}{l}\text { Bladder rupture } \\
\text { Retropubic hematoma }\end{array}$ & Open book fracture & $\begin{array}{l}\text { Flail chest } \\
\text { Lower leg amputation } \\
\text { Femoral artery transection }\end{array}$ & 50 & No \\
\hline
\end{tabular}

AP: anterior-posterior, AS: abdominal surgical site, CIV: common iliac vein, EIV: external iliac vein, inf:. inferior, ISS: injury severity score, Pt.: patient, sup.: superior. 
were excluded. Abdominal closure was defined as complete fascial closure, and microbiological specimens were obtained from surgical site tissues and drainages.

Outcome measures included microbiological analysis of the surgical site, unplanned implant removal due to infection, and in-hospital mortality. Demographic information, patient characteristics, and postoperative outcomes were recorded prospectively in an Excel database (Microsoft Corporation, Redmond, WA, USA). However, comprehensive statistical comparative analysis was not performed due to small number of enrolled patients.

\section{RESULTS}

A total of six patients met the inclusion criteria. Four of the six patients $(67 \%)$ were male, and the most common injury mechanism was anterior-posterior compression (67\%). The mean injury severity score was 38 (range, 27-59), and all patients had abdominal organ injuries and pelvic bone fractures of various types. There was no gross contamination of the surgical site in the first emergent surgery, except in one patient who underwent rectal transection (Table 1).

One patient died due to multi-organ dysfunction syndrome (MODS), corresponding to a mortality rate of $16.7 \%$. The patient died without abdominal closure due to an abdominal muscle defect, although he survived 60 days after the injury. The mean duration of open abdomen was 98 hours (range, 44-198), except in the one patient who died. Pelvic surgery was performed after abdominal closure in four patients, and the interval between abdominal closure and pelvic surgery was 98 hours. One patient died before abdominal closure and another patient underwent abdominal closure 4 days after pelvic surgery. Micro-organisms were identified in the abdominal surgical sites of five patients (83\%), with no micro-organisms identified in pelvic surgical sites. The species of the micro-organisms varied, and there was no unplanned implant removal due to SSI in any of the patients (Table 2).

Table 2. Clinical courses and outcomes

\begin{tabular}{|c|c|c|c|c|c|c|c|c|}
\hline Patients & Abdominal surgery & PS & $\begin{array}{c}\text { Duration of } \\
\text { open abdomen } \\
\text { (hours) }\end{array}$ & $\begin{array}{l}\text { Interval } \\
\text { between } \\
\text { AC and PS }\end{array}$ & $\begin{array}{l}\text { Abdominal } \\
\text { micro- } \\
\text { organisms }\end{array}$ & $\begin{array}{c}\text { Pelvic } \\
\text { micro- } \\
\text { organisms }\end{array}$ & Implantloss & $\begin{array}{l}\text { Survival } \\
\text { atdischarge }\end{array}$ \\
\hline 1 & $\begin{array}{l}\text { SMV repair } \\
\text { Distal pancreatectomy } \\
\text { Splenectomy } \\
\text { Hepatorrhaphy }\end{array}$ & $\begin{array}{c}\text { ORIF on } \\
\text { symphysis pubis }\end{array}$ & 29 & 206 & $\begin{array}{l}\text { E. coli } \\
\text { P. mirabilis } \\
\text { E. durans }\end{array}$ & No & No & Yes \\
\hline 2 & $\begin{array}{l}\text { Preperitoneal pelvic } \\
\text { packing }\end{array}$ & $\begin{array}{c}\text { ORIF on } \\
\text { symphysis pubis }\end{array}$ & 74 & 0 & MRAB & No & No & Yes \\
\hline 3 & $\begin{array}{l}\text { Preperitoneal pelvic } \\
\text { packing } \\
\text { Bladder repair }\end{array}$ & $\begin{array}{c}\text { ORIF on } \\
\text { symphysis pubis }\end{array}$ & 119 & 68 & E. faecalis & No & No & Yes \\
\hline 4 & $\begin{array}{l}\text { Preperitoneal pelvic } \\
\text { packing } \\
\text { External iliac vein ligation }\end{array}$ & ORIF on ilium & 57 & 117 & None & No & No & Yes \\
\hline 5 & $\begin{array}{l}\text { Pelvic packing } \\
\text { Iliac vessel ligation } \\
\text { Rectal closure }\end{array}$ & ORIF on ilium & $\begin{array}{l}\text { Died before } \\
\text { AC }\end{array}$ & $\begin{array}{l}\text { Died before } \\
\text { AC }\end{array}$ & E. faecalis & No & No & No \\
\hline 6 & $\begin{array}{l}\text { Preperitoneal pelvic } \\
\text { packing }\end{array}$ & $\begin{array}{c}\text { ORIF on symphysis } \\
\text { pubis and ilium }\end{array}$ & 91 & AC after PS & S. hominis & No & No & Yes \\
\hline
\end{tabular}

AC: abdominal closure, E. coli: Escherichia coli, E. durans: Enterococcus durans, E. faecalis: Enterococcus faecalis, MRAB: Multidrug resistant Acinetobacter baumannii, ORIF: open reduction internal fixation, P. mirabilis: Proteus mirabilis, PS: pelvic surgery, S. hominis: Staphylococcus hominis, SMV: superior mesenteric vein. 


\section{DISCUSSION}

Although DCL has been established as a standard therapy for severely injured patients, the therapeutic strategy for associated pelvic bone fractures has not been established. Nevertheless, Vallier et al. [7] reported the benefits of early fixation of the pelvis in those with MODS, pulmonary complications, and intensive care unit stay; however, SSI remains problematic and is feared. Contaminated wounds increase the risk for SSI depending on the abundance of pathogen [9]. The rate of SSI in abdominal injuries has been reported to be $13.8 \%$ [10] and can be as high as $25 \%$ in DCL [11].

Cross contamination is a primary reason surgeons hesitate in decision-making for pelvic surgery. The long midline incision used in DCL and the Pfannenstiel incision used in pelvic surgery usually share common space in the lower abdomen. In the cases of bladder or pelvic diaphragm, the surgical site for the abdomen and pelvis has open communication. Risk factors for orthopedic SSI include prolonged operative duration and open fracture(s) $[12,13]$. After DCL, the route for the pelvic approach is easily contaminated and, in fact, is expected in long operations for complex fracture(s).

Micro-organisms were identified in the abdominal surgical site in this study, with none in the pelvic surgical site. It was uncertain whether the pelvic surgical site was truly sterile because micro-organisms could have grown after drain removal or the bacterial culture yielded a false-negative result. However, no patients underwent implant removal or osteomyelitis during the follow-up period, meaning that the outcome of pelvic surgery was likely not influenced by open abdomen.

We were also wary of cross contamination. As such, this strategy was implemented in a very limited manner, and only in those in whom pelvic internal fixation was an essential and inevitable modality. This, however, effectively decreased the sample size and could be considered a limitation of this study. Although there was no implant removal or osteomyelitis, it is highly possible that the number of cases was too small to encounter all possible adverse events. However, given that previous studies have described the advantages of early pelvic fixation, this strategy merits serious consideration in individuals who sustain severe abdominopelvic injury.

\section{CONCLUSION}

Internal fixation of pelvic bone fracture(s) could be performed in the state of open abdomen, and advantages of early fixation may countervail the risk for cross contamination. This, however, needs further study to evaluate the timing of pelvic fixation in patients who undergo DCL.

\section{REFERENCES}

1. Duchesne JC, Kimonis K, Marr AB, Rennie KV, Wahl G, Wells JE, et al. Damage control resuscitation in combination with damage control laparotomy: a survival advantage. J Trauma 2010;69:46-52.

2. Roberts DJ, Bobrovitz N, Zygun DA, Ball CG, Kirkpatrick AW, Faris PD, et al. Indications for use of thoracic, abdominal, pelvic, and vascular damage control interventions in trauma patients: a content analysis and expert appropriateness rating study. J Trauma Acute Care Surg 2015;79:568-579.

3. Stahel PF, Smith WR, Moore EE. Current trends in resuscitation strategy for the multiply injured patient. Injury 2009;40(suppl 4):S27-35.

4. Chiara O, Cimbanassi S, Biffl W, Leppaniemi A, Henry S, Scalea $\mathrm{TM}$, et al. International consensus conference on open abdomen in trauma. J Trauma Acute Care Surg 2016;80:173-83.

5. Pape HC, Tornetta P 3rd, Tarkin I, Tzioupis C, Sabeson V, Olson SA. Timing of fracture fixation in multitrauma patients: the role of early total care and damage control surgery. J Am Acad Orthop Surg 2009;17:541-9.

6. Tuttle MS, Smith WR, Williams AE, Agudelo JF, Hartshorn CJ, Moore EE, et al. Safety and efficacy of damage control external fixation versus early definitive stabilization for femoral shaft fractures in the multiple-injured patient. J Trauma 2009;67:6025.

7. Vallier HA, Cureton BA, Ekstein C, Oldenburg FP, Wilber JH. Early definitive stabilization of unstable pelvis and acetabulum fractures reduces morbidity. J Trauma 2010;69:677-84.

8. Enninghorst N, Toth L, King KL, McDougall D, Mackenzie S, Balogh ZJ. Acute definitive internal fixation of pelvic ring fractures in polytrauma patients: a feasible option. J Trauma 
2010;68:935-41.

9. Owens CD, Stoessel K. Surgical site infections: epidemiology, microbiology and prevention. J Hosp Infect 2008;70 Suppl 2:310.

10. Morales CH, Escobar RM, Villegas MI, Castaño A, Trujillo J. Surgical site infection in abdominal trauma patients: risk prediction and performance of the NNIS and SENIC indexes. Can J Surg 2011;54:17-24.

11. Miller RS, Morris JA Jr, Diaz JJ Jr, Herring MB, May AK. Com- plications after 344 damage-control open celiotomies. J Trauma 2005;59:1365-71; discussion 1371-4.

12. Li J, Zhu Y, Liu B, Dong T, Chen W, Zhang Y. Incidence and risk factors for surgical site infection following open reduction and internal fixation of adult tibial plateau fractures. Int Orthop 2018;42:1397-403.

13. Moon GH, Cho JW, Kim BS, Yeo DH, Oh JK. Analysis of risk factors for infection in orthopedic trauma patients. J Trauma Inj 2019;32:40-6. 